\title{
First record of species of Liogenys (Coleoptera, Melolonthidae) associated with winter grain crops in Rio Grande do Sul (Brazil)
}

\author{
Mariana A. Cherman ${ }^{1}$, Jerson V. C. Guedes ${ }^{2}$, Miguel A. Morón ${ }^{3}$, Elder Dal Prá2, \\ Clérison R. Perini² \& Affonso H. Jung ${ }^{2}$
}

1Departamento de Zoologia, Universidade Federal do Paraná, 81531-980 Curitiba-PR, Brazil. marianabioar@gmail.com (corresponding author)
²Departamento de Defesa Fitossanitária, Universidade Federal de Santa Maria, 97105-900 Santa Maria-RS, Brazil. jerson.guedes@smail.ufsm.br,
elderdalpra@hotmail.com, clegaucho@hotmail.com, affonsojung@hotmail.com
${ }^{3}$ Red de Biodiversidad y Sistemática, Instituto de Ecologia, A. C., Apartado Postal 63, 91000 Xalapa, Veracruz, Mexico.miguel.moron@inecol.edu.mx

\begin{abstract}
First record of species of Liogenys (Coleoptera, Melolonthidae) associated with winter crops in Rio Grande do Sul (Brazil). Some species of Liogenys Guerín-Meneville, 1831 are known to cause damage to soybean, corn and other summer crops in the Brazilian "Cerrado" region. This work aimed to identify melolontid larvae associated with winter crops in Rio Grande do Sul state. Larvae and adults of Liogenys species were collected from the municipalities of Ijuí, Cruz Alta, Manoel Viana, São Luiz Gonzaga and São Francisco de Assis. The specimens were identified as L. bidenticeps Moser, 1919; L. fusca Blanchard, 1851, $L$. obesa Burmeister, 1855, and $L$. sinuaticeps Moser, 1918. This is the first record of these species associated with winter grain crops, for Rio Grande do Sul State. Biological and behavioral studies are necessary to confirm their association with host plants.
\end{abstract}

KEYWORDS. Lamellicornia; occurrence; taxonomy; white grubs.

RESUMO. Primeiro registro de ocorrência de espécies de Liogenys (Coleoptera, Melolonthidae) associadas a culturas de inverno no Rio Grande do Sul (Brasil). As espécies de Liogenys Guerín-Meneville, 1831 são conhecidas no "Cerrado" brasileiro por causar danos em culturas de verão como soja e milho. O trabalho teve por objetivo identificar as larvas de melolontídeos que ocorrem nas culturas de grãos de inverno no Rio Grande do Sul. Larvas e adultos de Liogenys foram coletados nos municípios de Ijuí, Cruz Alta, Manoel Viana, São Luiz Gonzaga e São Francisco de Assis. As espécies foram identificadas como Liogenys bidenticeps Moser, 1919, L. fusca Blanchard, 1851, L. obesa Burmeister, 1855 and L. sinuaticeps Moser, 1918. Trata-se do primeiro registro de ocorrência destas espécies associadas a culturas de grãos de inverno, no Estado de Rio Grande do Sul. São necessários estudos de biologia e comportamento para confirmar sua associação com plantas hospedeiras.

PALAVRAS-CHAVE: Corós; Lamellicornia; ocorrência; taxonomia.

White grub is the popular name given to the coleopterous larvae of the family Melolonthidae, Scarabaeoidea or Lamellicornia (sensu Endrödi 1966; Morón 1997a, 2010; Morón et al. 1997). Several species from this family are rhizophagous, feeding on various crops and are considered as pests in many parts of the world (Morón 1997a; Oliveira et al. 2004; Salvadori \& Silva 2004).

Damage by Liogenys spp. to corn, soybeans, wheat and oats has been registered mainly in Brazil (Santos \& Ávila 2009). Thirty-eight species from this genus have been recorded to this country (Evans 2003; Morón 2004), of which only two are considered pests of economically important crops. Both Liogenys suturalis Blanchard, 1851 and L. fusca Blanchard, 1851 were recorded on summer and winter grain crops in Mato Grosso do Sul State (Rodrigues et al. 2008), and the latter also occurs in various regions of Goiás State (Santos et al. 2008).

Melolonthidae species and their biology are little known in South America compared to those from Central and North
America (Morón 1997b). The genus Liogenys was originally classified in the Tribe Macrodactylini in the Dalla Torre (1912) and Blackwelder (1944) catalogues, but recent studies by Evans (2003) and Katovich (2008) suggest that the genus should be included in the Tribe Diplotaxini, since analysis of immature stages of some Liogenys species confirms their similarity to species of Diplotaxis Kirby, 1837. However, their phylogenetic relationships still need to be evaluated (Smith \& Evans 2005). This work aimed to identify larvae of melolontid species associated with winter crops in Rio Grande do Sul state.

Larvae of Melolonthidae collected in the municipalities of Ijuí, Cruz Alta, Manoel Viana, São Francisco de Assis and São Luiz Gonzaga during soil sampling in areas with oats, ryegrass, oats + Italian ryegrass and wheat crops, in 2009 and 2010, were reared to adults in the Laboratório de Entomologia da Universidade Federal de Santa Maria. Adults were collected in light traps in February 2010. Identifications were confirmed in the Laboratorio de Coleópteros 

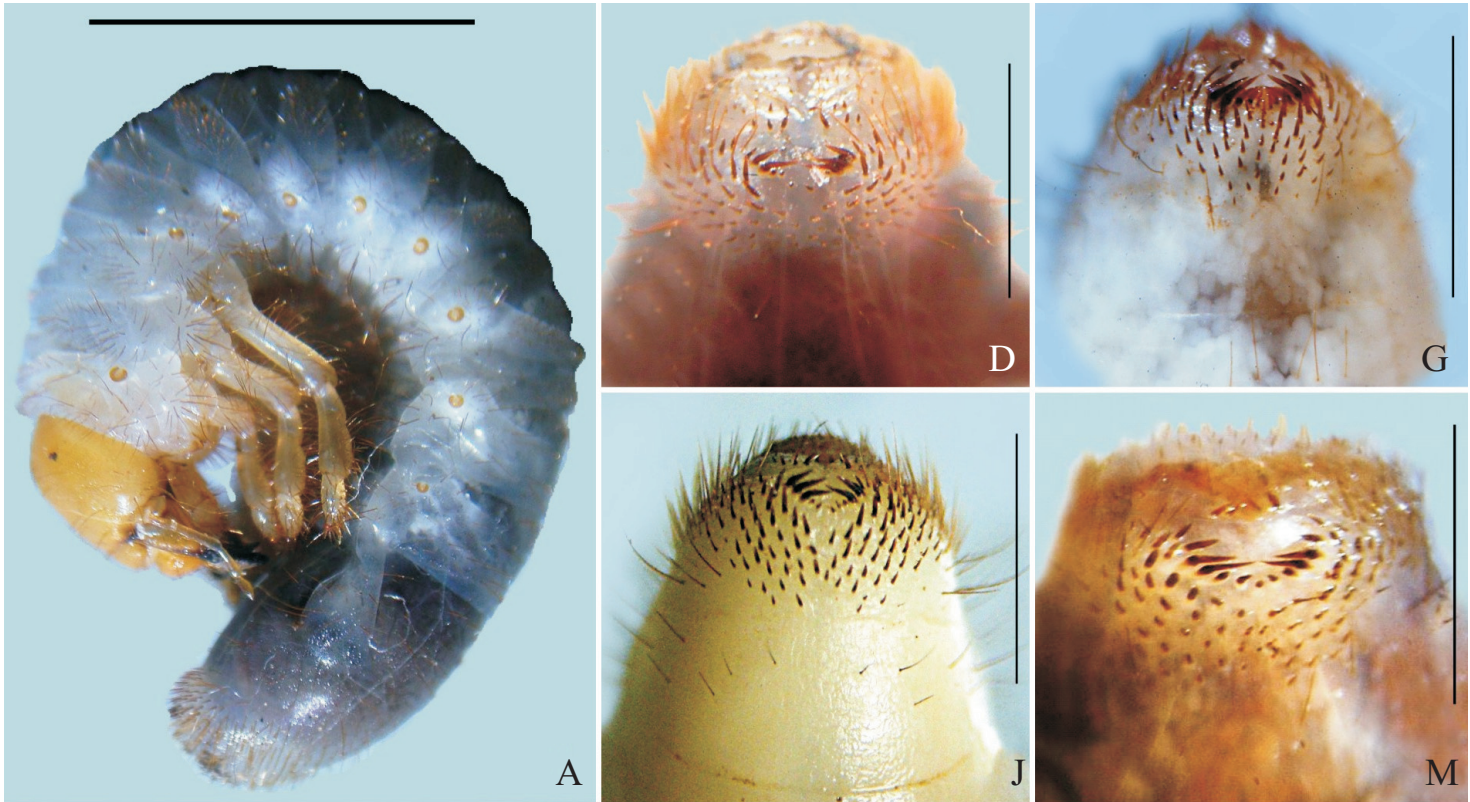

A
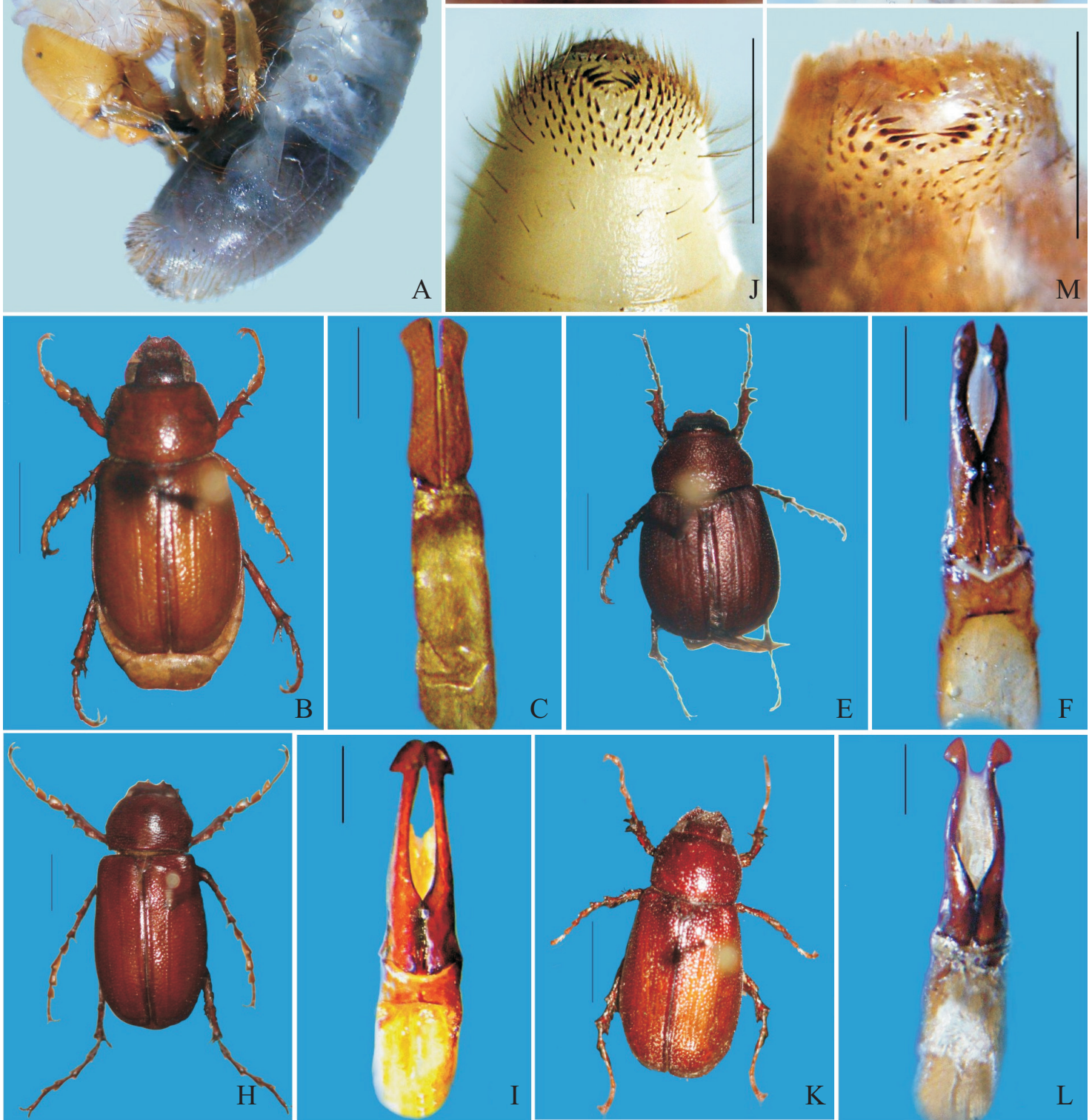

Fig. 1. Species of Liogenys in Rio Grande do Sul. A) third stage larva. L. sinuaticeps: B) adult, C) male genitalia, dorsal view, D) raster. L. obesa: E) adult, F) male genitalia, G) raster. L. fusca: H) adult, I) male genital, J) raster. L. bidenticeps: K) adult, L) male genitalia, M) raster. Scale lines: A = $10 \mathrm{~mm}, \mathrm{~B}$, $\mathrm{E}, \mathrm{H}, \mathrm{K}=5 \mathrm{~mm} ; \mathrm{C}, \mathrm{F}, \mathrm{I}, \mathrm{M}=2 \mathrm{~mm}, \mathrm{D}, \mathrm{G}, \mathrm{J}, \mathrm{M}=3 \mathrm{~mm}$.

Edafícolas, Instituto de Ecología A. C., Mexico. The material was deposited in Departamento de Defesa Fitossanitária, Universidade Federal de Santa Maria, Rio Grande do Sul.

Larvae of Liogenys (Fig. 1 A) possess the last antennomere with a sensorial macula, mandibles without a ventral stridulatory area raster with oblique palidia, which converge to the midline and with no defined septula and a "Y" shaped anal opening.
Adults are characterized by mandibles hidden under the edges of the clypeus, which have dentiform angles. The elytra have five longitudinal punctured striae and the legs possess a spur on the protibia and empodia with hairs on the pro- and mesotarsi. Sexual dimorphism of this species can be observed from the larger female body size and male tarsomeres, which are thickened. 
This is the first record for Liogenys bidenticeps Moser; L. fusca Blanchard, L. obesa Burmeister and L. sinuaticeps Moser, associated with winter grain crops in Rio Grande do Sul State. Liogenys bidenticeps has only been recorded from Brazil (Morón 2004; Evans 2003); L. fusca from Argentina, Bolivia and Brazil (Evans 2003); L. obesa from Argentina and Brazil (Blackwelder 1944; Frey 1969) and L. sinuaticeps from Brazil (Morón 2004; Evans 2003). The species discussed here can be identified by the following key. Since there are many species which damage economically important crops, biological and behavioral studies must also be carried out in the laboratory and field.

\section{Identification key for adults and larvae of Liogenys species associated with winter grain crops in Rio Grande do Sul}

1. Dorsal surface brownish-yellow, shiny; length $11 \mathrm{~mm}$; elytral width $5 \mathrm{~mm}$; parameres wide and straight, shorter than the basal piece, with apex amply spatulate and slightly divergent and with only a very slightly constricted apex (Fig. 1 B, C); larval raster with 12 obliquely spiniform pali of almost the same length, which converge incompletely to the midline (Fig. 1 D). Collected at Manoel Viana (oats + Italian ryegrass)

Liogenys sinuaticeps Moser, 1918

1'. Dorsal surface reddish-brown, shiny; parameres longer than the basal piece, with a strong apical constriction; larval never with 12 pali

2

2. Body widened posteriorly; length $9 \mathrm{~mm}$ and width $5 \mathrm{~mm}$; parameres only slightly curved, not projecting laterally; with lanceolate apex (Fig. $1 \mathrm{H}, \mathrm{I}$ ); larval raster with 10 spiniform pali disposed transversely, which converge incompletely to the midline; pali closer to the midline shorter than the lateral ones (Fig. $1 \mathrm{~J}$ ). Collected at São Luiz Gonzaga (oats) ............ Liogenys obesa Burmeister, 1855

2'. Body parallel-sided, not widened posteriorly; parameres laterally projected; larval raster with 13 oblique spiniform pali, converging incompletely to the midline; pali closer to the midline shorter

3. Length $13 \mathrm{~mm}$; width $7 \mathrm{~mm}$; parameres only slightly curved, convergent, apex rounded and harpoon-shaped laterally projected (Fig. $1 \mathrm{E}, \mathrm{F}$ ); larval raster with lateral pali long and thick (Fig. 1 G). Collected at São Francisco de Assis (oats), Manoel Viana (oats and Italian ryegrass) and Cruz Alta (oats) ...... Liogenys fusca Blanchard, 1851

3'. Length $11 \mathrm{~mm}$; width $5.5 \mathrm{~mm}$; parameres sinuous and divergent with spatulate apex and a rounded lateral projection (Figs. 1 B, C ); lateral pali long (Fig. 1 D). Collected at Ijuí (Italian ryegrass) and Cruz Alta (oats)

Liogenys bidenticeps Moser, 1919

\section{ACKNOWLEDGEMENTS}

To COTRIJUI, Cooperative staff and to the owners of the farms for ceding their areas for sampling. To CNPq
(Conselho Nacional de Desenvolvimento Científico e Tecnológico) and CAPES (Coordenação de Aperfeiçoamento de Pessoal de Nível Superior), for the scholarships.

\section{REFERENCES}

Blackwelder R. E. 1944. Checklist of the coleopterous insects of Mexico, Central America, the West Indies and South America. Part 2. Bulletin of the United States National Museum 185: 189-341.

Dalla Torre, K. W. von. 1912. Scarabaeidae; Melolonthidae I-III. Coleopterorum Catalogus 20: 1-290.

Endrödi, S. 1966. Monographie der Dynastinae (Coleoptera: Lamellicornia) I. Teil. Entomologische Abhandlungen - Staatliches Museum für Tierkunde Dresden 33: 1-457.

Evans, A.V. A. 2003. Checklist of the New World chafers (Coleoptera: Scarabaeidae: Melolonthinae). Zootaxa 211: 1-458

Frey, G. 1969. Betimmumgstabelle und Revision der Gattung Liogenys Guérrez. (Coleoptera-Melolonthinae-Macrodactylini). Entomologische Arbeiten aus dem Museum G. Frey 20: 36-64.

Katovich, K. 2008. A generic-level phylogenetic review of the Macrodactylini (Coleoptera: Scarabaeidae: Melolonthinae). Insecta Mundi 23: 1-78.

Morón, M. A. 1997a. Inventarios faunísticos de los Coleoptera Melolonthidae Neotropicais con potencial como bioindicadores. Giornale Italiano di Entomologia 8: 265-274.

Morón, M. A. 1997b. White grubs (Coleoptera: Melolonthidae: Phyllophaga Harris) in Mexico and Central America. A brief review. Trends in Entomology 1: 117-128.

Morón, M. A. 2004. Melolontídeos edafícolas, p. 133-166. In: J. R. Salvadori; C. J. Ávila \& M. T. B. da Silva (ed.). Pragas de solo no Brasil. Passo Fundo, Embrapa Trigo. Dourados, Embrapa Agropecuária Oeste. Cruz Alta, Fundacep Fecotrigo, xi+544 p.

Morón, M.A. 2010. Diversidad y distribución del complejo "gallina ciega" (Coleoptera: Scarabaeoidea), p. 41-63. In: L. A. Rodríguez del Bosque \& M. A. Morón (eds.). Plagas del suelo. Mundi Prensa México. xix+417 p.

Morón, M. A.; B. C. Ratcliffe \& C. Deloya. 1997. Atlas de los escarabajos de México. Coleoptera Lamellicornia 1. Familia Melolonthidae. Comisión Nacional para el conocimiento y uso de la Biodiversidad y Sociedad Mexicana de Entomología, México, xvi+280 p.

Oliveira, L. J.; B. Santos; J. R. P. Parra \& C. B. Hoffmann-Campo. 2004. Coró-da-soja, p. 167-190. In: J. R. Salvadori; C. J. Ávila \& M. T. Silva (Eds.). Pragas de solo no Brasil. Passo Fundo, Embrapa Trigo. Passo Fundo, Embrapa Trigo. Dourados, Embrapa Agropecuária Oeste. Cruz Alta, Fundacep Fecotrigo, xi+54 p.

Rodrigues, S. R, C. L. Barbosa, A. Puker, A. R. Abot \& S. Ide. 2008. Occurrence, biology and behavior of Liogenys fuscus Blanchard (Insecta, Coleoptera, Scarabaeidae) in Aquidauana, Mato Grosso do Sul, Brazil. Revista Brasileira de Entomologia 52: 637-640.

Salvadori, J. R. \& M. T. B. Silva. 2004. Coró-do-trigo, p. 211-232. In: J. R. Salvadori; C. J. Ávila \& M. T. Silva (Ed.), Pragas de solo no Brasil. Passo Fundo, Embrapa Trigo. Dourados, Embrapa Agropecuária Oeste. Cruz Alta, Fundacep Fecotrigo, xi+544 p.

Santos, V.\& C. J. Ávila. 2009. Aspectos Biológicos e Comportamentais de Liogenys suturalis Blanchard (Coleoptera: Melolonthidae) no Mato Grosso do Sul. Neotropical Entomology 38: 734-740.

Santos A. C.; A. F. Bueno; R. C. O. F. Bueno \& S. S. Vieira. 2008. Chemical control of white grub Liogenys fuscus (Blanchard 1851) (Coleoptera: Melolonthidae) in cornfields. BioAssay 3 (5). Available at: $<$ www.bioassay.org.br/articles/3.5>. Acessed 22th October 2009.

Smith, A. B. T. \& A. V. Evans. 2005. A supplement to the checklist of the New World chafers (Coleoptera: Scarabaeidae: Melolonthinae) with notes on their tribal classification. Zootaxa 1032: 29- 60 .

Received 31/5/2011; accepted 6/11/2011

Editor: Lucia Massutti de Almeida 